Journal of Pharmaceutical Science and Medical Research

ISSN 2614-4840 (print) 2614-6118 (online)

Vol. 1 No. 1 Tahun 2018

\title{
UJI TOKSISITAS EKSTRAK ETANOL KAYU CEREMAI (Phyllanthus acidus L) TERHADAP LARVA UDANG Artemia salina DENGAN METODE BRINE SHRIMP LETHALITY TEST (BST)
}

\author{
TOXICITY TEST OF ETANOL EXTRACT OF OTAHEITE GOOSEBERRY WOOD \\ (Phyllanthus acidus) AGAINTS BRINE SHRIMP LARVAE (Artemia salina Leach) \\ USING BRINE SHRIMP LETHALITY TEST (BST) METHOD
}

\author{
Desi Kusumawati \\ ${ }^{1}$ Prodi Farmasi FIKS, Universitas PGRI Madiun, Indonesia \\ desi@unipma.ac.id
}

\begin{abstract}
Abstrak
Penggunaan kayu ceremai sebagai obat tradisional perlu didukung oleh informasi ilmiah tentang khasiat dan efek samping yang ditimbulkan. Tujuan penelitian ini adalah untuk membuktikan potensi toksisitas ekstrak etanol kayu ceremai menurut metode Brine Shrimp Lethality Test (BST). Merupakan penelitian eksperimental. Hewan uji berupa 160 larva Artemia salina Leach dibagi dalam 6 kelompok. Tiap kelompok terdiri dari 10 ekor dengan replikasi 3 kali. Bahan uji ekstrak etanol kayu ceremai diberikan lewat media yang berisi larva. Konsentrasi ekstrak untuk masing-masing kelompok adalah $500 \mu \mathrm{g} / \mathrm{ml}, 300$ $\mu \mathrm{g} / \mathrm{ml}, 200 \mu \mathrm{g} / \mathrm{ml}, 100 \mu \mathrm{g} / \mathrm{ml}, 50 \mu \mathrm{g} / \mathrm{ml}$ dan $0 \mu \mathrm{g} / \mathrm{ml}$ sebagai kontrol negatif. Hasil didapatkan berdasarkan jumlah larva yang mati 24 jam setelah pemberian bahan uji. LC $\mathrm{C}_{50}$ ekstrak etanol kayu ceremai ditentukan dengan analisis probit menggunakan SPSS 16.0 for windows. Senyawa yang diduga terdapat dalam ekstrak etanol kayu ceremai yang diduga memiliki sifat toksik dilihat dengan skrining fitokimia. Rata-rata kematian larva pada konsentrasi $500 \mu \mathrm{g} / \mathrm{ml}, 300 \mu \mathrm{g} / \mathrm{ml}, 200 \mu \mathrm{g} / \mathrm{ml}, 100 \mu \mathrm{g} / \mathrm{ml}, 50 \mu \mathrm{g} / \mathrm{ml}$ dan $0 \mu \mathrm{g} / \mathrm{ml}$ berturut-turut adalah 9,$33 ; 7,33 ; 4,67 ; 3,33 ; 2$ dan 0 . Semakin tinggi konsentrasi ekstrak menyebabkan jumlah kematian larva yang semakin tinggi. Didapatkan harga $\mathrm{LC}_{50}$ dari ekstrak etanol kayu ceremai adalah $275,035 \mu \mathrm{g} / \mathrm{ml}$. LC S0 $_{0}<1000 \mu \mathrm{g} / \mathrm{ml}$ menunjukkan ekstrak etanol kayu ceremai memiliki potensi toksisitas terhadap larva udang Artemia salina Leach.
\end{abstract}

Kata kunci: Phyllanthus acidus L, kayu ceremai, brine shrimp lethality test, toksisitas 


\title{
Journal of Pharmaceutical Science and Medical Research \\ ISSN 2614-4840 (print) 2614-6118 (online) \\ Vol. 1 No. 1 Tahun 2018
}

\begin{abstract}
The use of Otaheite gooseberry wood as a traditional medicine needs to be supported by scientific information about the efficacy and side effect. The objective of this research is to prove the presence of toxicity potency in ethanol extract of otaheite gooseberry wood using BST methods. An experimental research. Total sampel were 160 Brine shrimp (Artemia salina Leach) larvae. Ten larvae used in each 6 groups with 3 times replication. Each group was consecutively given $500 \mu \mathrm{g} / \mathrm{ml}, 300 \mu \mathrm{g} / \mathrm{ml}, 200 \mu \mathrm{g} / \mathrm{ml}, 100 \mu \mathrm{g} / \mathrm{ml}, 50 \mu \mathrm{g} / \mathrm{ml}, 0 \mu \mathrm{g} / \mathrm{ml}$ concentrate of ethanol extract of otaheite gooseberry wood, the sixth group was used as control. Data obtained by calculating amount of died larva in 24 hours after treatment. LC $C_{50}$ value was analyzed by probit analysis using SPSS 16.0 for windows. Presumable compound contained in extract etanol Otaheite gooseberry wood in which have tokcixity testcase by "skrining fitokimia". The average mortality of larvae at a concentration of 500, 300, 200, 100,50 , and $0 \mu \mathrm{g} / \mathrm{ml}$ consecutively were 9,33; 7,33; 4,67;3,33; 2 and 0 . The higher the extract concentration led to a growing number of high larval mortality. LC $C_{50}$ value of fruit extract of otaheite gooseberry wood was 275,035 $\mathrm{\mu g} / \mathrm{ml}$. LC $C_{50}<1000 \mu \mathrm{g} / \mathrm{ml}$ indicates ethanol extract of otaheite gooseberry wood own a potential toxicity to larvae of Artemia salina Leach.
\end{abstract}

Key words: Phyllanthus acidus L, otaheite gooseberry, brine shrimp lethality test, toxicity.

\section{PENDAHULUAN}

Kanker adalah suatu penyakit sel dengan ciri gangguan atau kegagalan mekanisme pengatur multiplikasi dan fungsi homeostasis lainnya pada organisme multiseluler (Nafrialdi dan Ganiswara, 2005). Kanker merupakan salah satu penyakit yang paling ditakuti, karena penyakit ini sangat sulit disembuhkan dan seringkali mematikan. Pada dasarnya kanker disebabkan oleh beberapa faktor antara lain faktor karsinogen lingkungan yang dapat menimbulkan mutasi gen atau modifikasi sel (Katzung, 1998).

Salah satu tanaman yang diketahui berpotensi sebagai antikanker secara empiris adalah Phyllanthus acidus L atau sering kita kenal dengan tanaman ceremai. Ceremai merupakan salah satu dari 22 tanaman obat Indonesia yang digunakan sebagai obat antikanker (Sukardiman, 1999). Penelitian antikanker tanaman ceremai telah dilakukan. (Sukardiman et al, 2000) menunjukkan bahwa ekstrak metanol akar ceremai pada dosis 300 $\mathrm{mg} / \mathrm{kgBB}$ mampu menghambat pertumbuhan kanker serta terjadinya $40 \%$ nekrosis sel kanker fibrosarkoma mencit hasil induksi benzo (a) piren. Kandungan ceremai adalah alkaloid, tanin, flavonoid, lignin, fenolik, dan terpenoid, selain itu juga mengandung vitamin C. Selain golongan alkaloid, golongan senyawa flavonoid, steroid dan terpenoid juga berfungsi sebagai antikanker. Berdasarkan hal tersebut maka dilakukan uji toksisitas lebih lanjut terhadap kayu ceremai.

Golongan senyawa yang lebih spesifik dalam kayu ceremai dapat diketahui dengan ekstraksi menggunakan pelarut etanol. Ekstrak diuji toksisitasnya dengan metode Brine Shrimp Lethality Test (BST) sehingga dapat diketahui apakah ekstrak tersebut memiliki efek toksik terhadap larva udang Artemia salina L. dan pada konsentrasi berapakah yang memberikan efek toksik terhadap larva udang Artemia salina $\mathrm{L}$.

Brine Shrimp Lethality Test (BST) merupakan salah satu metode untuk menguji bahan-bahan yang bersifat toksik dengan uji toksisitas terhadap larva udang Artemia salina L. Metode ini merupakan salah satu metode 


\section{Journal of Pharmaceutical Science and Medical Research \\ ISSN 2614-4840 (print) 2614-6118 (online) \\ Vol. 1 No. 1 Tahun 2018}

yang banyak digunakan untuk pencarian senyawa antikanker baru yang berasal dari tanaman. Hasil uji toksisitas dengan metode ini telah terbukti memiliki korelasi dengan daya sitotoksik senyawa antikanker. Selain itu, metode ini juga mudah dikerjakan, murah, cepat dan cukup akurat (Nurhayati et al, 2006).

Data yang diperoleh dari metode ini berupa prosentase kematian larva udang Artemia salina L. Data tersebut digunakan untuk menentukan nilai $\mathrm{LC}_{50}$ ekstrak etanol. Ekstrak dapat dikatakan memiliki aktivitas antikanker dengan metode BST jika harga LC $_{50}$ kurang dari $1000 \mu \mathrm{g} / \mathrm{ml}$ (Meyer et al, 1982).

\section{METODE}

Metode Penelitian yang digunakan dalam penelitian ini adalah metode eksperimental laboratorium.

\section{Alat dan bahan \\ Bahan yang digunakan kayu ceremai dari desa Talok, Turen, Malang, Jawa Timur, larva udang (Artemia salina L), alkohol 96\%, Air laut asli. Alat yang digunakan peralatan ekstraksi, corong hisap, rotary evaporator, seperangkat alat gelas, oven, seperangkat alat uji BST.}

\section{Prosedur kerja \\ Cara pembuatan ekstrak etanol kayu ceremai}

Ditimbang $250 \mathrm{~g}$ serbuk simplisia kayu ceremai, ditambahkan dengan pelarut etanol 96\% sampai terendam dan selanjutya ditutup rapat. Kemudian biarkan selama 24 jam, saring filtratnya dengan corong hisap. Maserasi ini diulang lagi 2 kali dengan pelarut etanol yang baru. Filtrat yang diperoleh dari pelarut tersebut dipekatkan dengan evaporator hingga diperoleh ekstrak kental. Jumlah etanol 96\% yang digunakan sebagai pelarut dalam maserasi ini adalah 10 kali berat simplisia yaitu 2,5 liter pada setiap kali perendaman.

\section{Persiapan hewan uji larva udang Artemia salina $\mathbf{L}$}

Telur Artemia salina ditimbang $50 \mathrm{mg}$ kemudian dimasukkan ke dalam gelas berisi $500 \mathrm{ml}$ air laut yang sudah disaring. Sambil diberi aerasi, telur akan menetas setelah 18-24 jam dan larvanya disebut naupli. Naupli siap untuk uji BST setelah 48 jam diambil dengan cara memipetnya (Nurhayati et al, 2006).

\section{HASIL DAN PEMBAHASAN}

\section{Ekstraksi Kayu Ceremai}

Proses ekstraksi dengan cara maserasi dilakukan dengan menggunakan pelarut total yaitu etanol 96\%. Penggunaan pelarut total dimaksudkan agar zat-zat kandungan yang terdapat dalam kayu ceremai dapat tersari dengan satu pelarut. Hasil ekstrak kayu yang diperoleh dapat dilihat dalam Tabel 1.

Tabel 1 Hasil ekstraksi serbuk simplisia kayu ceremai

\begin{tabular}{cccc}
\hline $\begin{array}{l}\text { Berat serbuk } \\
\text { simplisia }(\mathrm{g})\end{array}$ & Pelarut & $\begin{array}{c}\text { Berat rendemen } \\
(\mathrm{g})\end{array}$ & $\begin{array}{c}\text { Prosentase } \\
\text { rendemen }(\% \mathrm{~b} / \mathrm{b})\end{array}$ \\
\hline 250 & Etanol $96 \%$ & 8,2059 & 3,28 \\
\hline
\end{tabular}

\section{Uji BST}

Jumlah larva udang Artemia salina $L$ yang mati pada setiap konsentrasi ekstrak etanol kayu ceremai dengan uji BST dapat dilihat pada Tabel 2. Nilai $\mathrm{LC}_{50}$ rata-rata ekstrak kayu ceremai yang dianalisis probit dengan SPSS 16 for windows dapat dilihat pada Tabel 3. 
Tabel 2 Pengaruh berbagai konsentrasi ekstrak etanol kayu ceremai (Phyllanthus acidus L) terhadap kematian larva udang Artemia salina selama 24 jam.

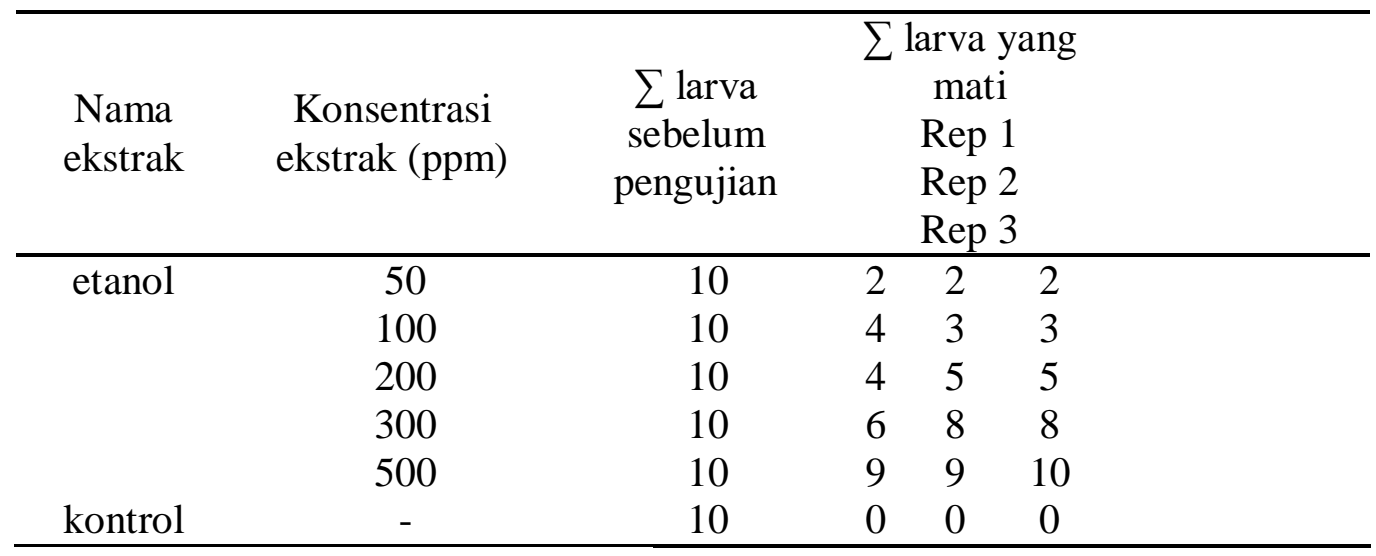

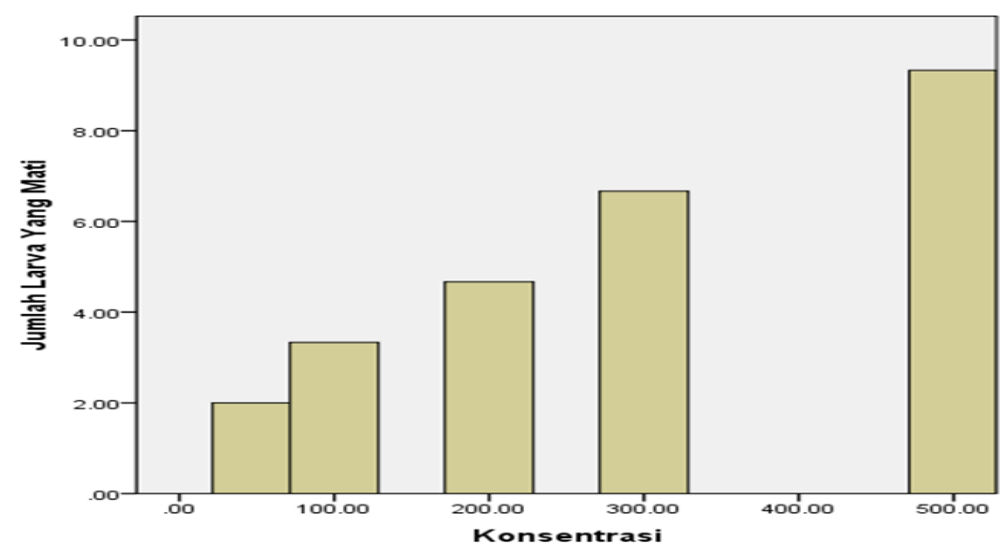

Grafik 1 Pengaruh berbagai konsentrasi ekstrak etanol kayu ceremai terhadap kematian larva udang Artemia salina $L$

Tabel 3. $\mathrm{LC}_{50}$ rata-rata ekstrak etanol kayu ceremai.

\begin{tabular}{ccc}
\hline Ekstrak & LC $_{50}$ rata-rata $(\mathrm{ppm})$ & Kategori \\
\hline etanol & 275,035 & Toksik \\
\hline
\end{tabular}

Ekstrak etanol kayu ceremai termasuk dalam kategori toksik karena memiliki harga LC $C_{50}$ kurang dari 1000 ppm (Meyer, 1982 cit Widianti, 2010). Dengan demikian dapat dikatakan ekstrak etanol kayu ceremai poten sebagai antikanker karena dapat menyebabkan kematian $50 \%$ larva udang dengan konsentrasi yang cukup rendah yaitu 275,035 ppm.

\section{KESIMPULAN}

Hasil penelitian dapat disimpulkan bahwa ekstrak etanol kayu ceremai memiliki efek toksik terhadap larva udang Artemia salina $L$ dengan metode $\mathrm{BST}$ dengan nilai $\mathrm{LC}_{50}$ ratarata yaitu sebesar 275,035. Perlu dilakukan penelitian lebih lanjut yaitu fraksinasi dan isolasi senyawa aktif dari ekstrak etanol kayu ceremai yang bersifat toksik terhadap larva udang Artemia salina Leach dan uji aktivitas antikanker pada kultur sel kanker manusia secara in vitro dan in vivo.

\section{DAFTAR PUSTAKA}

Gabiswara, S.G, Seteabudy, R., Suyanta, F.D, Purwantyastuti, dan Nafrialdi. 2005. Farmakologi dan Terapi Edisi Keempat 
Cetakan Keempat, 517. Bagian Farmakologi Fakultas Kedokteran Universitas Indonesia, Jakarta.

Katzung B.G. 1998. Farmakologi Dasar dan Klinik. Edisi Keempat. Penerjemah: Bagian Farmakologi FKUA. Jakarta: Penerbit Salemb. Medika.

Meyer B.N, Ferrigni N.R, Putnam J.E, Jacobsen L.B, Nichols D.E, dan McLaughin J.L. 1982. Brine Shrimp: A Convenient General Bioassay for Active Plant Constituent. Planta Medica, 45; 31-33.

Nurhayati A.P.D., Nurlita A., Rachmat F. 2006. Uji Toksisitas Ekstrak Eucheuma alvarezii terhadap Artemia salina sebagai Studi Pendahuluan Potensi Antikanker. Akta Kimindo Vol. 2 No. 1. p. $41-46$.

Sukardiman., Santa, I.G.P., dan Rahmadany, 1999, Efek Anti Kanker Isolat Flavonoid dari Benalu Mangga (Dendrophtoe petandra), Cermin Dunia Kedokteran, 122:5-7.

Sukardiman, Hadi P, Sofia M, Sismindari. 2000. Penapisan Senyawa Antikanker dari Tanaman Obat Indonesia dengan Molekul Target Enzim DNA Topoisomerase. Laporan Penelitian Domestic Collaborative Research Grant (DCRG). 

